\title{
Utilization of dissolved protein and amino acids in the northern Sargasso Sea
}

\author{
Richard G. Keil*, David L. Kirchman \\ University of Delaware, College of Marine Studies, 700 Pilottown Road, Lewes, Delaware 19958, USA
}

\begin{abstract}
The chemical composition and degradation of dissolved amino acids and glucose by bacteria were investigated in the northern Sargasso Sea. Multiple pools of amino acids were discerned based on microbial reactivity. Concentrations of dissolved free amino acid (DFAA) were highest in the surface waters, where rapid utilization of DFAA accounted for $<20 \%$ of the measured bacterial growth requirements for $\mathrm{C}$ and $\mathrm{N}$. Dissolved combined amino acid (DCAA) and protein (using the BCA assay) concentrations were 10 - to 25 -fold higher than that of DFAA. In surface waters, DCAA was largely identifiable as protein $(\sim 100 \%)$, but most of the DCAA at depth $(>100 \mathrm{~m})$ did not respond to the protein assay $(<50 \%)$. In surface waters, protein was the dominant form of organic nitrogen used to support bacterial growth, supporting 20 to $65 \%$ of the calculated bacterial $\mathrm{N}$ demand. In deeper waters, utilization of a modified form of protein (glucosylated protein) accounted for the highest portion of the bacterial growth demands. Free and combined amino acids did not meet the full bacterial $N$ demand at depth, and other, unmeasured nitrogen sources were required. Similar to trends in utilization, maximum uptake rate $\left(V_{\max }\right)$ for protein was highest in surfaces waters. Modified protein had higher $V_{\max }$ in deep waters, consistent with the longer turnover time of this pool of DCAA and the likelihood that it is produced in the surface and transported to depth each winter during mixing events
\end{abstract}

KEY WORDS: Amino acids - Bacteria - Sargasso Sea - Dissolved organic matter - Glucose - Protein . DFAA

\section{INTRODUCTION}

The dissolved amino acid pool consists of both free (DFAA) and combined (DCAA) amino acids, the latter being those amino acids released by acid hydrolysis (Keil \& Kirchman 1993). Although concentrations of DFAA are usually in the low nanomolar range, fluxes are high enough to support a large albeit variable fraction of heterotrophic bacterial growth (Keil \& Kirchman 1991a, Middelboe et al. 1995). DCAA concentrations are higher, usually nanomolar to micromolar, and DCAA turnover also supports a significant portion of bacterial growth (Keil \& Kirchman 1993, Rosenstock \& Simon 1993, Middelboe et al. 1995). DFAA are utilized preferentially over DCAA until concentrations or turnover rates of DFAA become very low (Keil \& Kirch-

\footnotetext{
- Present address: School of Oceanography, Box 357940, University of Washington, Seattle, Washington 98195-7940, USA.E-mail: rickkeil@ocean.washington.edu
}

man 1993, Middelboe et al. 1995). Generally, DFAA and DCAA account for roughly $50 \%$ of the bacterial nitrogen demand (Keil \& Kirchman 1991a, 1993, Middelboe et al. 1995) and $25 \%$ of the bacterial carbon demand in estuarine and coastal systems (Hagström et al. 1984, Middelboe et al. 1995, Kirchman \& Wheeler 1998).

The DCAA pool is chemically complex (Billen 1991, Keil \& Kirchman 1993). Various proteins, peptides bound in humic substances, and amino acids complexed with detrital materials may all have different susceptibilities to microbial degradation (e.g. Tanoue et al. 1995, Nagata \& Kirchman 1996, Tanoue 1996). Based on chemical assays, most of the DCAA pool appears to be protein, at least in the Delaware Bay, USA (Keil \& Kirchman 1993). When bioassays are used to distinguish reactivities of the DCAA pool in the Delaware Bay, multiple fractions are discerned (Keil \& Kirchman 1993). One fraction of DCAA is similar to protein freshly extracted from algae and is utilized readily by natural bacterial assemblages. Another frac- 
tion exhibits the limited bioreactivity of glucosylated protein, which are proteins with carbohydrates covalently bonded to amines. A third component of the DCAA pool does not react in chemical assays for protein and probably consists of amino acids complexed with or sorbed to other materials, e.g. membrane proteins bound in a lipopolysaccharide matrix or peptides trapped in a matrix of uncharacterized materials. This fraction presumably is utilized more slowly than the other 2 fractions.

Despite several previous studies on amino acid cycling and protease activity (Billen 1991), little is known about DCAA compositions or utilization in oligotrophic waters. The goal of this study was to examine amino acid cycling in the Sargasso Sea, where DFAA concentrations are very low and turnover rapid (Suttle et al. 1991).

\section{MATERIALS AND METHODS}

Samples were obtained on July 27, 1990 (34. $59.55^{\prime}$ $\left.\mathrm{N}, 73^{\circ} 00.11^{\prime} \mathrm{W}\right)$ and on February $7,1991\left(37^{\circ} 25.05^{\prime} \mathrm{N}\right.$, $72^{\circ} 34.85^{\prime} \mathrm{W}$ ) in the northern Sargasso Sea near the eastern edge of the Gulf Stream. Water was collected using acid-cleaned Niskin bottles on board the RV 'Cape Henlopen', transferred to acid washed polypropylene containers and immediately used for sample analysis. All analyses of natural microbial assemblages were conducted in muffled $\left(500^{\circ} \mathrm{C}\right)$ glass test tubes and completed onboard ship.

Amino acid concentrations were measured by HPLC after precolumn derivatization with ortho-phthaldialdehyde (OPA) (Lindroth \& Mopper 1979, Keil \& Kirchman 1991b). Samples for DCAA were hydrolyzed in triplicate in the vapor phase. Precision of DCAA estimates is better than $10 \%$. Glycine and threonine were not resolved using the HPLC gradient employed for this study. Protein concentrations were determined using the BCA (bicinchoninic acid) method (Keil \& Kirchman 1993, Nguyen \& Harvey 1994). We previously compared this method with other protein assays and determined that the BCA assay provides the closest estimates to DCAA concentrations in Delaware Bay waters (Keil \& Kirchman 1993). Two other protein assays (Bradford and Quanti gold) were also used on the samples reported here (data not shown). Samples ( $250 \mathrm{ml}$ of $0.22 \mu \mathrm{m}$ filtrate) were concentrated by ultrafiltration through 1000 Dalton (D) cutoff filters (Amicon) under $1300 \mathrm{~mm}$ of $\mathrm{Hg}$. All samples were kept cold during filtration. The protein standard used was ribulose 1,5-bisphosphate carboxylase (RuBPcase) made up in UV-oxidized, $3000 \mathrm{~m}$ Sargasso Sea water. Samples were analyzed in triplicate along with UV-oxidized deep Sargasso Sea water as a blank.
During the July cruise, glucose concentrations were estimated spectrophotometrically after reaction with the enzyme hexokinase-glucose-6-phosphate dehydrogenase (Sigma Scientific Co.). Carbohydrates were determined spectrophotometrically using both the anthrone reaction (Strickland \& Parsons 1972) and the MBTH ( 3 methyl-2-benzoathiazolinone hydrazone hydrochloride) method (Johnson \& Sieburth 1977. Pakulski \& Benner 1994).

For the rate and kinetic measurements, the large subunit of RuBPcase was uniformly labeled with ${ }^{14} \mathrm{C}$ amino acids by in vitro translation (final specific activity $=30 \mu \mathrm{Ci} \mathrm{mg}{ }^{-1}$; Keil \& Kirchman 1993). A portion of the RuBPcase was artificially modified by promoting the abiotic glucosylation of exposed amine residues (Keil \& Kirchman 1993). This glucosylated protein will hereafter be referred to as modified protein.

Bacterial utilization of protein was examined in triplicate by adding $0.10 \mathrm{\mu g}$ of RuBPcase to $10 \mathrm{ml}$ of unfiltered seawater (final concentration $10 \mathrm{ug} \mathrm{l}^{-1}$, or $\sim 1 \%$ of the DCAA pool) and incubating the sample in the dark at ambient temperature for 0.2 to $1 \mathrm{~h}$ (Keil \& Kirchman 1993). Control samples were filtered immediately. After incubation, the samples were filtered onto $0.45 \mu \mathrm{m}$ filters, rinsed twice with filtered seawater, and radioassayed. To measure DFAA and glucose assimilation, a $\left[{ }^{3} \mathrm{H}\right]$-L-amino acid mixture $\left(220 \mathrm{nCi} \mathrm{nmol}^{-1}\right)$ or $\left[{ }^{3} \mathrm{H}\right]$-glucose $\left(40 \mu \mathrm{Ci} \mathrm{nmol}^{-1}\right)$ was added at final concentrations of $0.1 \mathrm{nM}$ and incubated as described above.

Kinetic experiments to estimate the maximum uptake rate $\left(V_{\max }\right)$ and $\left(K_{\mathrm{m}}+S\right)$ values for proteins (where $K_{\mathrm{m}}$ is the half-saturation constant and $S$ the in situ substrate concentration) were conducted in triplicate as described by Wright \& Hobbie (1965) and Keil \& Kirchman (1993). Rate and kinetic experiments were only conducted on samples from shallower than $900 \mathrm{~m}$ in July and $500 \mathrm{~m}$ in February. As shown previously (Fuhrman \& Ferguson 1986, Keil \& Kirchman 1993), $K_{\mathrm{m}}$ is typically the smaller component $(<35 \%)$ of $K_{\mathrm{m}}+S$, and therefore the combined $K_{m}+S$ value generally reflects the in situ concentration of protein bioavailable protein.

Bacterial production was estimated from $\left[{ }^{3} \mathrm{H}\right]$-thymidine $\left(70 \mu \mathrm{Ci} \mathrm{nmol}^{-1}\right)$ and $\left({ }^{14} \mathrm{C}\right)$-leucine $\left(60 \mu \mathrm{Ci} \mathrm{nmol}^{-1}\right)$ incorporation using the dual labeled technique of Chin-Leo \& Kirchman (1988). Samples were processed similarly to the method used for DFAA and protein uptake except that final concentrations were 5 and $10 \mathrm{nM}$ for the thymidine and leucine, respectively. Rates were converted to bacterial production using conversion factors derived in the Delaware Estuary (Hoch 1991), and then to carbon demand ( $C$ demand) assuming an average cellular carbon content of $20 \mathrm{fg} \mathrm{C}$ cell $^{-1}$ and assuming a growth efficiency of $20 \%$ (unpubl. data). Bacterial production was converted to 
bacterial nitrogen demand ( $\mathrm{N}$ demand) using a conversion factor of $5.4 \mathrm{fg} \mathrm{N}$ cell $^{-1}$ (Lee \& Fuhrman 1987).

\section{RESULTS}

Total DFAA concentrations were very low $(<10 \mathrm{nM})$ and had a slight maximum in surface waters (Fig. 1). In the deep waters, DFAA were at the limits of our analytical technique. DCAA concentrations were also highest in the surface waters and decreased with depth. DCAA values ranged from 167 to $810 \mathrm{nM}$ (Fig. 1). In water deeper than $200 \mathrm{~m}$, there was little difference in DCAA between the 2 sampling periods. However, in surface waters DCAA concentrations were $-25 \%$ higher in July than in February. The amount of protein, estimated using the BCA assay, ranged from 60 to $813 \mathrm{nM}$ (Fig. 1). Protein concentrations estimated by the kinetic assays ranged from 37 to $1175 \mathrm{nM}$, and were congruent with the BCA assay data. In both February and July the proportion of DCAA identifiable as protein was highest in the surface waters $(40$ to $100 \%)$ while in the deeper waters only 20 to $50 \%$ of the DCAA responded to the protein assays. Consequently the ratio of protein to DCAA decreased with depth (Fig. 1). Other protein assays for these same samples (Bradford, Quanti gold) confirm this shift in response with depth (data not shown).

The composition of the DFAA pool was dominated by the amino acids alanine, glycine-threonine and serine. No significant changes were observed in the composition as a function of sampling date or depth. On a mole-percent basis, the DCAA pool was also enriched in glycine-threonine, alanine and serine (Fig. 2). In July, when there was a strongly developed thermocline at $100 \mathrm{~m}$, there was a statistically significant enrichment of serine and lysine in the deep water DCAA pool relative to the surface water (Student's ttest, $\mathrm{p}<0.05$; Fig. 2). In February, when the thermocline was not as strongly developed and was deeper $(\sim 175 \mathrm{~m})$, there was no significant difference in the compositions of the surface and deep DCAA pools.

Dissolved free sugar (unhydrolyzed MBTH) and glucose (enzymatic assay) concentrations in the surface waters were all $<100 \mathrm{nM}$, and values were at the detection limit ( $15 \mathrm{nM})$ in the deeper waters (Fig. 3). Carbohydrate concentrations were also highest in the surface waters, and ranged between 0.75 and $4.0 \mu \mathrm{M}$. Good agreement was observed between the anthrone and MBTH methods in the surface waters, but in the deep waters the MBTH method detected roughly twice the concentration of carbohydrates as the anthrone method (Fig. 3).

Bacterial carbon and nitrogen demand was highest in the surface waters (Fig. 4). Except for 1 sample $(90 \mathrm{~m}$

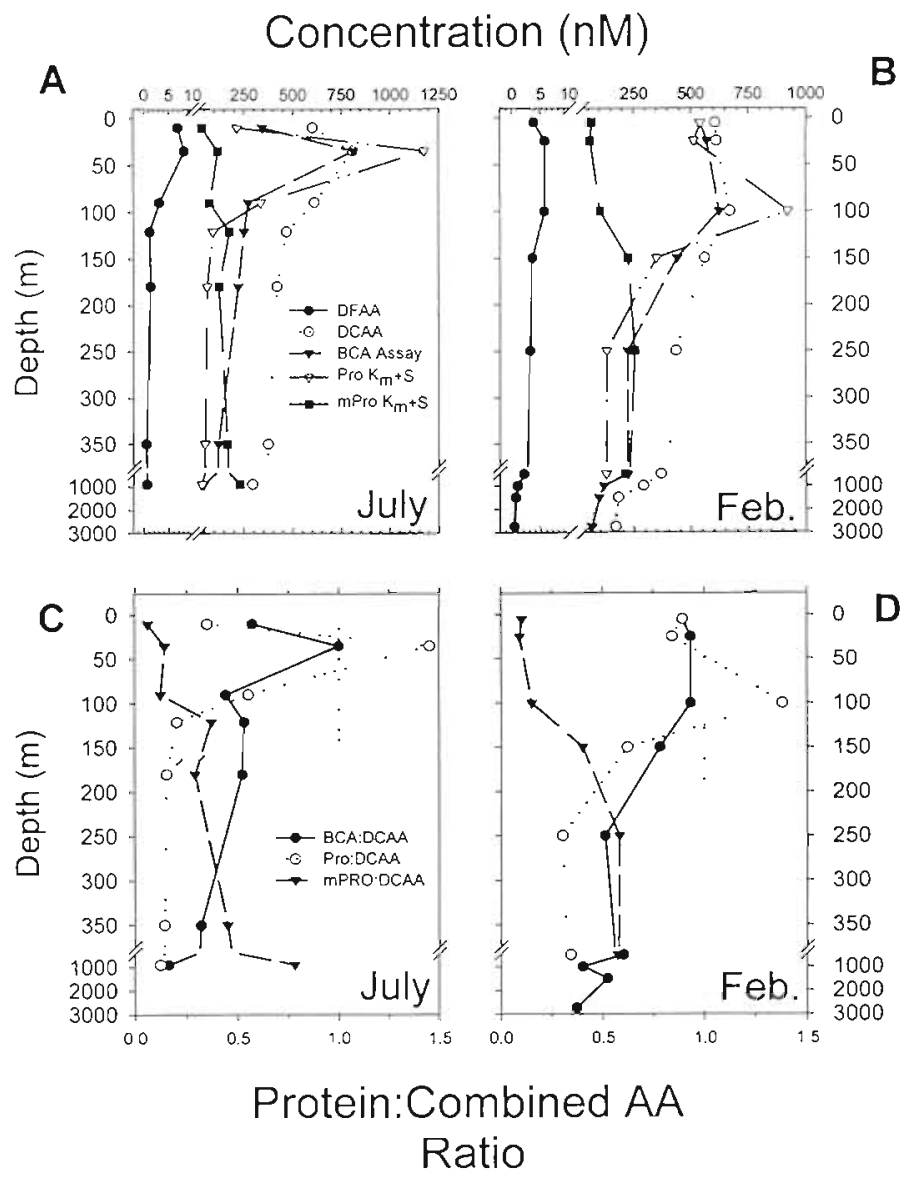

Fig. 1. Concentrations and ratios of dissolved combined amino acid (DCAA) and protein in the northern Sargasso Sea. (A, B) Estimates of dissolved free amino acid (DFAA), DCAA, bicinchoninic acid (BCA) protein assay, and kinetic parameters for protein (Prol and modified protein (mPro) as a function of depth for samples taken in July and February. (C, D) Ratio of protein to DCAA using the BCA data and the 2 kinetic assays in July

in July) there was good agreement between thymidine- and leucine-derived bacterial growth requirements. For comparison to utilization rates, the leucinederived $\mathrm{C}$ and $\mathrm{N}$ demands were used because this growth estimate most directly relates to protein cycling and it incorporates changes in cell volume (unbalanced growth; Chin-Leo \& Kirchman 1990). DFAA contributed $<20 \%$ of the $\mathrm{C}$ or $\mathrm{N}$ required for growth in all samples, and the contribution was maximal in the surface waters (Table 1, Fig. 5). Glucose contributed $<10 \%$ of the $\mathrm{C}$ demand. Protein contributed 5 to $50 \%$ of the estimated $N$ demand, and $<25 \%$ of the $C$ demand. As with DFAA, protein supported the highest percentage of bacterial growth in surface waters. The modified protein accounted for 5 to $50 \%$ of the measured $\mathrm{N}$ demand. In contrast to DFAA and protein use, modified protein utilization did not change substantially with depth (Fig. 5). In total, the utilization of 
DFAA, protein and modified protein supported 40 to $80 \%$ of the observed bacterial $\mathrm{N}$ demand in July and 60 to $100 \%$ of the $\mathrm{N}$ demand in February.

The maximum uptake rate ( $V_{\max }$ ) of protein and modified protein ranged from 0.09 to $3.5 \mu \mathrm{M} \mathrm{N} \mathrm{h}{ }^{-1}$ (Fig. 6). In surface waters ( $<50 \mathrm{~m}), V_{\max }$ of fresh protein was higher than the modified protein $V_{\max }$. In the deeper water, the $V_{\max }$ of fresh protein was lower than that for modified protein. Turnover times for fresh protein were generally faster than those for the modified
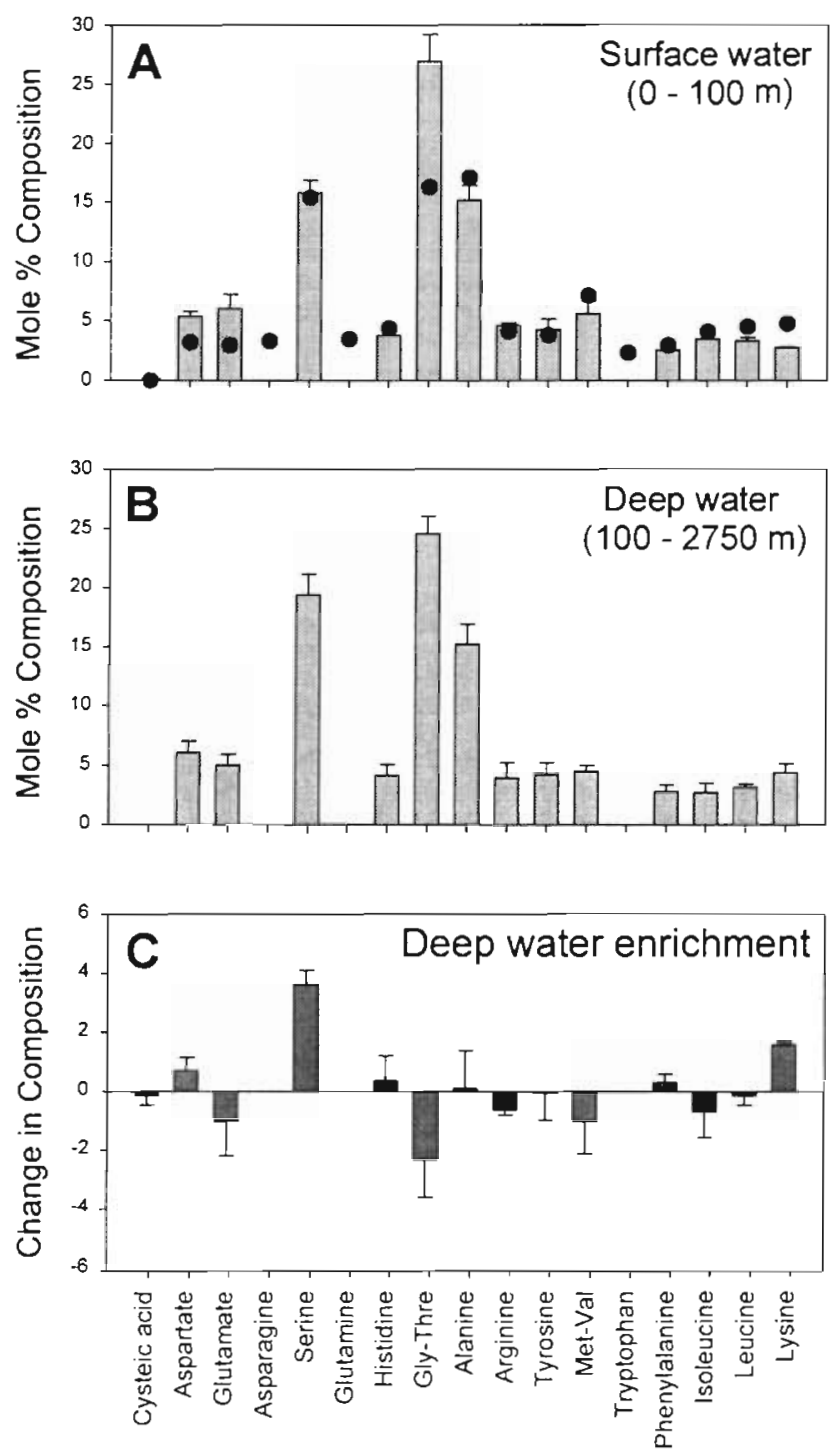

Fig. 2. Mole percent composition of DFAA (surface only; and DCAA in (A) surface and (B) deep water during July. DFAA are not shown for deep water because concentrations were below the detection limit of approximately $0.5 \mathrm{nM}$ per individual amino acid. (C) Change in composition of DCAA between the surface and the deep water samples in July. Error bars denote 1 standard deviation about the mean where $n=4$ in the surface waters and $n=12$ in the deep waters protein. The average turnover times for fresh protein in July and February were 50 and 26 h (Table 2), whereas the turnover of modified protein averaged 414 and $334 \mathrm{~h}$ in July and February, respectively.

Table 1. Percent of carbon demand accounted for by glucose, dissolved free amino acid (DFAA), protein and modified protein in the Sargasso Sea. Carbon demand was calculated assuming a growth efficiency of $20 \%$; see 'Materials and methods'

\begin{tabular}{|c|c|c|c|c|c|}
\hline \multirow{2}{*}{$\begin{array}{l}\text { Depth } \\
\text { (m) }\end{array}$} & \multicolumn{5}{|c|}{ Percent of carbon demand } \\
\hline & Glucose & DFAA & Protein & $\begin{array}{l}\text { Mod. } \\
\text { protein }\end{array}$ & Total \\
\hline \multicolumn{6}{|l|}{ July } \\
\hline 10 & 4 & 4 & 4 & 8 & 20 \\
\hline 35 & 4 & 1 & 9 & 7 & 21 \\
\hline 90 & 5 & 1 & 8 & 5 & 19 \\
\hline 121 & 3 & 1 & 1 & 9 & 14 \\
\hline 180 & 2 & 1 & 1 & 7 & 11 \\
\hline 350 & 1 & 2 & 1 & 6 & 10 \\
\hline 910 & 1 & 1 & 1 & 9 & 12 \\
\hline \multicolumn{6}{|c|}{ February } \\
\hline 5 & NA & 4 & 11 & 5 & 20 \\
\hline 25 & NA & 1 & 7 & 4 & 12 \\
\hline 100 & NA & 1 & 3 & 8 & 12 \\
\hline 150 & NA & 1 & 7 & 9 & 17 \\
\hline 250 & NA & 1 & 13 & 4 & 18 \\
\hline 500 & NA & 1 & 9 & 7 & 17 \\
\hline
\end{tabular}

Table 2. Estimated turnover time, in hours, of protein, modified protein, dissolved free amino acids (DFAA) and glucose in Sargasso Sea surface and deep waters. Glucose data available for July only

\begin{tabular}{|c|c|c|c|c|}
\hline \multirow{2}{*}{$\begin{array}{l}\text { Depth } \\
\text { (m) }\end{array}$} & \multicolumn{3}{|c|}{ Turnover time (h) } & \multirow[b]{2}{*}{ Glucose } \\
\hline & Protein & $\begin{array}{l}\text { Mod. } \\
\text { protein }\end{array}$ & DFAA & \\
\hline \multicolumn{5}{|l|}{ July } \\
\hline 10 & 17 & 475 & 5.3 & 1.8 \\
\hline 35 & 52 & 785 & 7.0 & 9.3 \\
\hline 90 & 9 & 346 & 2.2 & 0.2 \\
\hline 121 & 48 & 217 & 6.7 & 1.2 \\
\hline 180 & 70 & 298 & 7.0 & 0.1 \\
\hline 350 & 82 & 329 & 0.6 & $<0.1$ \\
\hline 910 & 73 & 448 & 3.6 & $<0.1$ \\
\hline Average & 50 & 414 & 4.6 & 1.7 \\
\hline \multicolumn{5}{|l|}{ February } \\
\hline 5 & 4 & 182 & 3.2 & \\
\hline 25 & 17 & 223 & 4.1 & \\
\hline 100 & 72 & 430 & 0.4 & \\
\hline 150 & 31 & 257 & 2.4 & \\
\hline 250 & 12 & 326 & 1.5 & \\
\hline 500 & 20 & 589 & 2.9 & \\
\hline Average & 26 & 334 & 2.4 & \\
\hline Overall average & 39 & 377 & 3.6 & \\
\hline
\end{tabular}




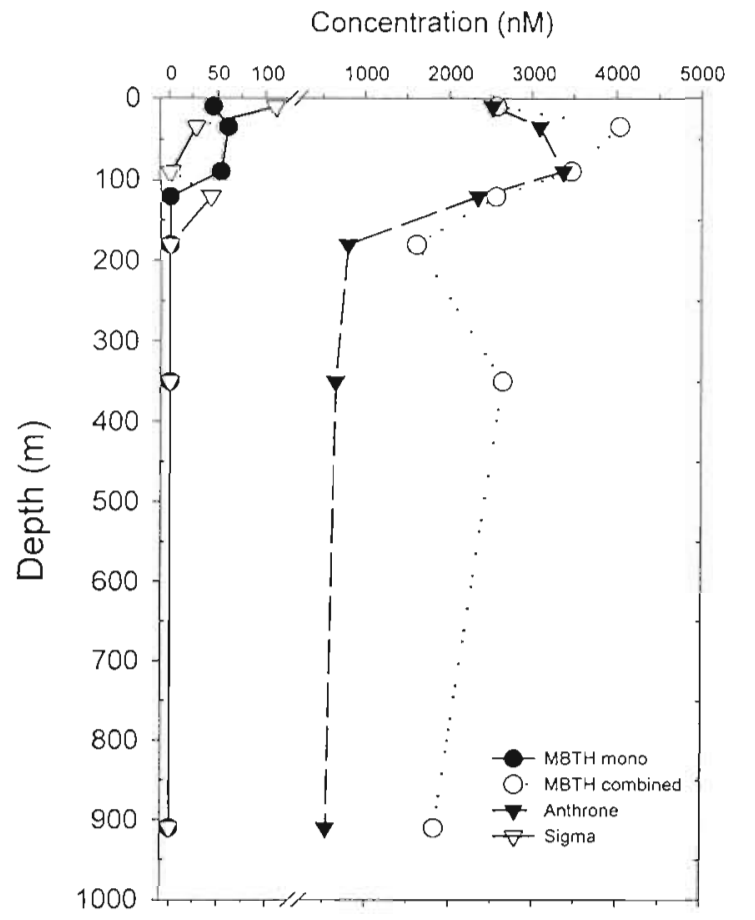

Fig. 3. Concentration of dissolved free and combined sugars during the July sampling. Units are standardized to glucose equivalents for the MBTH ( 3 methyl-2-benoathiazolinone hydrazone hydrochloride) and anthrone data

\section{DISCUSSION}

Dissolved organic matter (DOM) accumulates in Sargasso Sea surface waters during summer months and is then exported in the winter via mixing and water transport (Carlson et al. 1994). Superimposed upon this is the production and consumption of DOM that occurs on shorter time scales. Reactive DOM cycles at a rate similar to that of primary production (Hansell et al. 1995) and only 6 to $7 \%$ of the DOM in surface waters can be considered reactive on the time scale of days to weeks (Carlson \& Ducklow 1996). Suttle et al. (1991) estimated that DFAA utilization could account for about $20 \%$ of bacterial $\mathrm{C}$ or $\mathrm{N}$ demand in Sargasso Sea surface waters, and measured turnover rates from hours to days. Our estimates of DFAA concentrations and turnover are consistent with these data and further suggest that although quantitatively an unimportant component of the DOM, free amino acids serve as an important substrate for heterotrophic bacteria in the surface waters of the Sargasso Sea. Similarly, glucose accounts for only a small portion of the DOM and contributes $<20 \%$

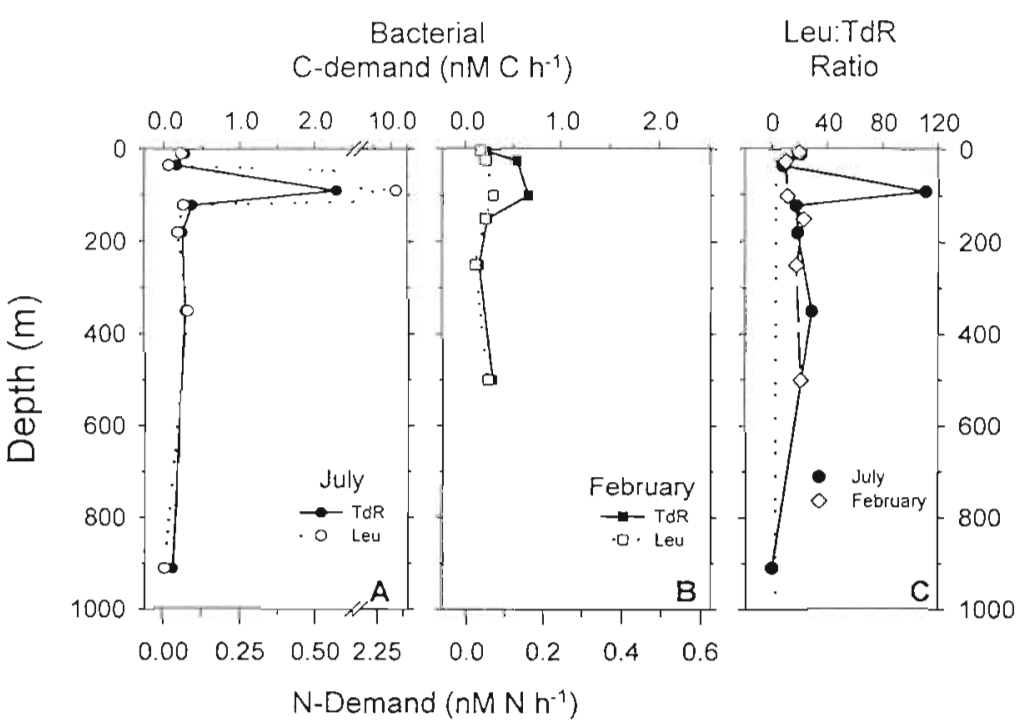

Fig. 4. Bacterial carbon and nitrogen demand during (A) July and (B) February measured using thymidine and leucine incorporation. (C) Ratio of leucine to thymidine incorporation for both sampling periods

toward the bacterial growth demand. Free glucose estimates and turnover are consistent with measurements in the Gulf of Mexico by Skoog et al. (in press).

There has been little research on DCAA or protein utilization in oligotrophic environments. Working in the surface waters of the Southern California Bight, Hollibaugh \& Azam (1983) determined that protein degradation was correlated with both primary productivity and bacterial growth. Williams (1986) measured concentrations similar to ours in the Santa Monica Basin and suggested that DCAA and DFAA concentra-

\section{$\Sigma \% \mathrm{~N}$-demand Supported}

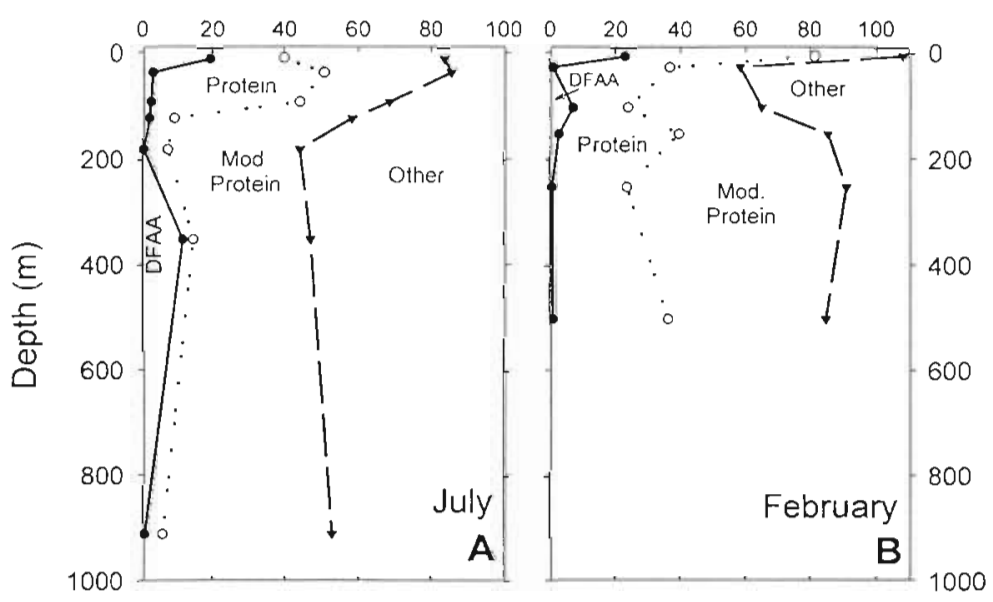

Fig. 5. Cumulative percentage of bacterial nitrogen demand accounted for by DFAA, protein and modified protein assimilation in (A) July and (B) February 


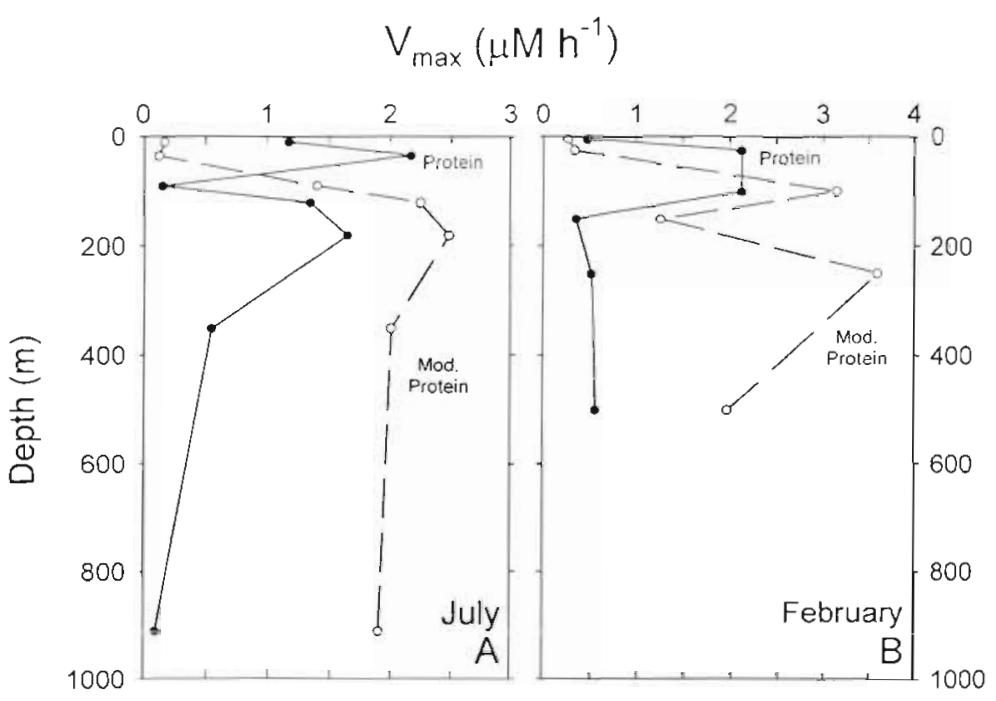

Fig. 6. Maximum uptake velocities ( $V_{\max }$ ) for the utilization of protein and modified protein in (A) July and (B) February

tions reflected different local sources; phytoplankton productivity at the surface and bacterial denitrification in the deep basin. Azam et al. (1992) noted that the DCAA content of deep waters ( $>200 \mathrm{~m})$ in the Southern California Bight was decoupled from bacterial growth. They concluded that while DCAA is an important substrate fueling bacterial growth in surface waters, the DCAA in deep waters cycles slowly (over decadal time scales or longer) and is not a readily available source of energy for deep water heterotrophic bacteria. Our data for the Sargasso Sea are consistent with this view of DCAA cycling. We observed rapid cycling of protein in the surface waters and decreased turnover in the deeper water. Overall, DCAA utilization (protein + modified protein) accounted for all bacterial $\mathrm{N}$ and approximately one fifth of the $\mathrm{C}$ demand in surface waters, and 10 to $80 \%$ of the $\mathrm{C}$ and $\mathrm{N}$ demand of the heterotrophic community in the deeper water. Carbon and nitrogen sources other than amino acids were necessary to support the measured growth of bacteria in the deep waters. Despite meeting a substantial fraction of the bacterial growth requirements, protein turnover in the deep water was still $\sim 10$ - to 30 -fold slower than that of the surface pool.

Protein (BCA assay and kinetic assays) comprised a smaller fraction of the DCAA pool in deep water relative to the surface water. There are several potential explanations for this. Some protein assays are relatively insensitive to low molecular weight peptides. If the deep DCAA pool is composed primarily of small peptides, then the BCA protein assay could be underestimating the size of the pool. While the sensitivity of the BCA assay to peptide length has not been evalu- ated (Nguyen \& Harvey 1994), in our comparison of protein assays in the Delaware Estuary we observed consistently higher yields using the BCA assay relative to the Bradford assay, which is known to be insensitive to peptides (Mayer et al. 1986), suggesting that insensitivity to peptides may not contribute significantly to our observed results. The mechanism of the BCA assay is to reductively cleave peptide bonds, especially those near tryptophan (Smith et al. 1985). If the deep water DCAA pool is depleted in tryptophan, underestimates of protein could occur. We did not measure the tryptophan concentrations in this study, but Keil (unpubl.) estimated trypotophan in oligotrophic Pacific waters and did not observe a significant decrease in the mole percentage of tryptophan in the deep water relative to the surface water. Deep water proteins could simply have a lower response relative to proteins in surface waters. However, Nyugen \& Harvey (1994) evaluated the response of several marine proteins and plankton samples and observed no significant difference between these natural proteins and the RuBPcase standard we used. The good agreement in profile shape and general concentration between the BCA chemical assay and the kinetic assay for fresh protein suggests that the concentration of bioavailable protein in the deep waters is indeed less than in the surface waters.

The deep water protein pool could contain amino acids, peptides and proteins bound in a matrix that renders them unavailable to react with the protein reagent. Based on amino acid racemization data, Lee \& Bada (1977) hypothesized that the deep water DCAA pool of the Sargasso Sea was largely composed of bacterial cell wall materials, either as cell walls in living bacteria or as cellular debris. This hypothesis is consistent with the work of Tanoue et al. (1995), who observed intact cell wall proteins in the DCAA pool of oligotrophic Pacific waters, and of McCarthy et al. (1996), who observed that the ultrafilterable DOM pool contained nitrogen almost exclusively found in the amide (peptide bond) form. Nagata \& Kirchman (1996) observed that proteins bound in cell walls or adsorbed to colloid surfaces were not as easily degraded by bacteria as free proteins. Thus, it is possible that the diminished protein content of the DCAA pool in the deep Sargasso Sea water is due to shielding of protein from the assay, and this shielding may also contribute to the decreased lability of the deep water DCAA. It is interesting to note that we observed a slight enrichment of serine and lysine in the deep water DCAA. These 2 amino acids may play a role in either binding 
proteins to matrices (most likely for lysine, which is hydrophobic) or in keeping the DCAA component in solution (most likely for serine, which is soluble). The enrichment of these amino acids was also observed by Hubberten et al. (1994), who suggested that all deep water DCAA in the Greenland Sea were bound into humic-like organic matrices that rendered them refractory. Our yields of DCAA are roughly a factor of 2 higher than that of Lee \& Bada (1977) for the Sargasso Sea. This is most likely due to the enhanced yield of amino acids from vapor-phase hydrolysis (Keil \& Kirchman 1991b), but since Lee \& Bada (1977) used cation exchange chromotography, differences due to HPLC methodology cannot be ruled out. Although we observed a higher yield than Lee \& Bada (1977), our data are consistent with DCAA concentration in other systems (Williams 1986, Azam et al. 1992, Hubberten et al. 1994).

Bacterial utilization of protein was most important in surface waters and decreased to roughly 5 to $20 \%$ of the bacterial $\mathrm{N}$ demand in the deep water. Conversely, the modified protein supported 30 to $50 \%$ of the observed bacterial $\mathrm{N}$ demand at all depths. Thus, bacterial populations throughout the water column actively utilized both forms of protein. However, the $V_{\max }$ for protein utilization was highest in the surface waters and the $V_{\max }$ for modified protein was highest in the deep water. This suggests that bacterial assemblages at the surface were adapted to utilize fresh protein, as would be expected since primary production and thus protein release are highest in surface waters (Sellner 1981). If the modified protein is used as a model compound for the semi-labile DCAA component, then bacterial assemblages living at depth appear to be more adapted to utilizing semi-labile proteins. Since protein is relatively labile, and DCAA mixed or transported to depth would require months or years to reach depths significantly below the thermocline (Carlson et al. 1994), it is reasonable to expect DCAA at depth to be more like the modified protein than the unmodified protein.

If an average dissolved organic carbon (DOC) concentration in the Sargasso Sea in July is taken to be 70 and $55 \mu \mathrm{M}$ for surface waters and deep waters, respectively (Carlson et al. 1994), then amino acids comprise roughly 3 to $6 \%$ of the DOC pool. This is consistent with William's (1986) estimate for the Santa Monica Basin. The concentrations of carbohydrates that we measured are 3 to $4 \times$ higher than that of DCAA. Using similar reasoning, the carbohydrate pool comprises 15 to $40 \%$ of the DOC. This is a lower percentage than has been reported for other areas of the ocean (Pakulski \& Benner 1994), but is consistent with previous reports that the carbohydrate pool is much larger than the DCAA pool (e.g. McCarthy et al. 1996). Utilization of these 2 pools may be coupled. In batch culture work, Keil \& Kirchman (1991a) noted that glucose additions increased the utilization of DFAA, and Hagström et al. (1984) measured a constant 2:1 ratio of carbohydrate: protein utilization ratio. Skoog et al. (in press) showed that additions of ultrafiltered DOM could stimulate glucose turnover. Our data on carbohydrate utilization are limited to the turnover of glucose. Applying Hagström et al.'s (1984) carbohydrate to protein utilization ratio to our data suggests that protein and carbohydrate utilization in the Sargasso Sea can account for about $50 \%$ of the bacterial carbon demand in both surface and deep waters.

Overall, DCAA utilization in the Sargasso Sea is consistent with the paradigm for DOM cycling in the region (Carlson et al. 1994). Labile material (e.g. DFAA and glucose) cycle rapidly in surface waters and contribute little to the standing stock of DOM. Materials of intermittent reactivity (e.g. proteins and carbohydrates with turnover times of days to weeks) also support heterotrophic growth in the surface waters and contribute to the DOM pool because of temporal differences in the rates of production and consumption (Sellner 1981 , Carlson et al. 1994). The semi-refractory DCAA pool (e.g. modified protein with month to year turnover times) survives in surface waters long enough to be advected or overturned into the deep water where it is slowly remineralized. Finally, the refractory DCAA pool, characterized here only as the 'background' DCAA content of the deep water, does not appear to react on short time scales

Acknowledgements. We thank Bob Bowden, Anne Woomer, Bill Ullman, Steve Skrabal and Matt Hoch for analytical assistance. We also thank the captain and crew of the RV 'Cape Henlopen'. We acknowledge significant and important discussions with Toshi Nagata and the comments of 3 anonymous referees which helped in our data interpretation and presentation

\section{LITERATURE CITED}

Azam F, Smith DC, Carlucci AF (1992) Bacterial transformation and transport of organic matter in the Southern California Bight. Prog Oceanogr 30:151-166

Billen G (1991) Protein degradation in aquatic environments. In: Chrost JC (ed) Bacterial enzymes in aquatic environments. Springer, London, p 122-142

Carlson CA, Ducklow HW (1996) Growth of bacterioplankton and consumption of dissolved organic carbon in the Sargasso Sea. Aquat Microb Ecol 10:69-85

Carlson CA, Ducklow HW, Michaels AF (1994) Annual flux of dissolved organic carbon from the euphotic zone in the northwestern Sargasso Sea. Nature 371:405-408

Chin-Leo G, Kirchman DL (1988) Estimating bacterial production in marine waters from the simultaneous incorporation of thymidine and leucine. Appl Environ Microbiol 54:1934-1939

Chin-Leo G, Kirchman DL (1990) Unbalanced growth in nat- 
ural assemblages of marine bacterioplankton. Mar Ecol Prog Ser 63:1-8

Fuhrman HA, Ferguson RL (1986) Nanomolar concentrations and rapid turnover of dissolved free amino acids in seawater: agreement between chemical and microbiological measurements. Mar Ecol Prog Ser 33:237-242

Hagström $\AA$, Ammerman JW, Henrichs SM, Azam F (1984) Bacterioplankton growth in seawater: II. Organic matter utilization during steady-state growth in seawater cultures. Mar Ecol Prog Ser 18:41-48

Hansell DA, Bates NR, Gundersen K (1995) Mineralization of dissolved organic carbon in the Sargasso Sea. Mar Chem 51:201-212

Hoch MP (1991) Ammoniun uptake by heterotrophic marine bacteria: environmental control and nitrogen isotope biogeochemistry. PhD thesis, University of Delaware, Lewes

Hollibaugh JT, Azam F (1983) Microbial degradation of dissolved proteins in seawater. Limnol Oceanogr 28(6): $1104-1116$

Hubberten U, Lara RJ, Kattner G (1994) Arnino acid composition of seawater and dissolved humic substances in the Greenland Sea. Mar Chem 45:121-128

Johnson K, Sieburth J (1977) Dissolved carbohydrates in seawater. I, A precise spectrophotometric analysis for monosaccharides. Mar Chem 5:1-13

Keil RG, Kirchman DL (1991a) Contribution of dissolved free amino acids and ammonium to the nitrogen requirements of hetertrophic bacterioplankton. Mar Ecol Prog Ser 73:1-10

Keil RG, Kirchman DL (1991b) Dissolved combined amino acids in marine waters as determined by a vapor-phase hydrolysis method. Mar Chem 33:243-259

Keil RG, Kirchman DL (1993) Dissolved combined amino acids: chemical form and utilization by marine bacteria. Limnol Oceanogr 38(6): 1256-1270

Kirchman DL, Wheeler PA (1998) Uptake of ammonium and nitrate by heterotrophic bacteria and phytoplankton in the sub-Arctic Pacific. Deep-Sea Res I 45(2-3):347-365

Lee C, Bada JL (1977) Dissolved amino acids in the equatorial Pacific, the Sargasso Sea and Biscayne Bay. Limnol Oceanogr 22:502-510

Lee S, Fuhrman JA (1987) Relationships between biovolume and biomass of naturally derived marine bacterioplankton. Appl Environ Microbiol 53:1298-1303

Lindroth P, Mopper K (1979) High performance liquid chromatographic determination of subpicomole amounts of amino acids by precolumn fluorescence derivatization with o-phthaldialdehyde. Anal Chem 51:1667-1674

Mayer LM, Schick L, Setchell FW (1986) Measurement of pro-

Editorial responsibility: Farooq Azam,

La Jolla, California, USA tein in nearshore marine sediments. Mar Ecol Prog Ser 30 $224-227$

McCarthy M, Hedges J, Benner R (1996) Major biochemical composition of dissolved high molecular weight organic matter in seawater. Mar Chem 55:281-297

Middelboe M, Borch NH, Kirchman DL (1995) Bacterial utilization of dissolved free amino acids, dissolved combined amino acids and ammonium in the Delaware Bay estuary: effects of carbon and nitrogen limitation. Mar Ecol Prog Ser 128:109-120

Nagata T, Kirchman DL (1996) Bacterial degradation of proteins adsorbed to model submicron particles in seawater. Mar Ecol Prog Ser 132:214-248

Nguyen RT, Harvey HR (1994) A rapid microscale method for the extraction and analysis of protein in marine samples. Mar Chem 45:1-14

Pakulski JD, Benner R (1994) Abundance and distribution of carbohydrates in the ocean. Limnol Oceanogr 39(4):930-940

Rnsenstock B, Simon M (1993) Use of dissolved combined and free amino acids by planktonic bacteria in Lake Constance. Limnol Oceanogr 38(7):1521-1531

Sellner KG (1981) Primary productivity and the flux of dissolved organic matter in several marine environments. Mar Biol 65:101-112

Skoog A, Biddanda B, Benner R (1999) Glucose flux in the upper water column of the Gulf of Mexico: contribution to heterotrophic bacterial production. Limnol Oceanogr (in press)

Smith PK, Krohn RI, Hermanson GT, Mallia AK, Gartner FH, Provenzano MD, Fujimoto EK, Goeke NM, Olsen BJ, Klenk DC (1985) Measurement of protein using bicinchoninic acid. Anal Chem 150:76-85

Strickland R, Parsons TR (1972) A practical handbook of seawater analysis. Bull Fish Res Board Can 167

Suttle CA, Chan AM, Fuhrman JA (1991) Dissolved free amino acids in the Sargasso Sea: uptake and respiration rates, turnover times, and concentrations. Mar Ecol Prog Ser 70:189-199

Tanoue E (1996) Characterization of the particulate protein in Pacific surface waters. J Mar Res 54:967-990

Tanoue E, Nishiyama S, Kamo M, Tsugita A (1995) Bacterial membranes: possible source of a major dissolved protein in seawater. Geochim Cosmochim Acta 59(12):2643-2648

Williams PM (1986) Chemistry of the dissolved and particulate phases in the water column. In: Eppley RW (ed) Lecture notes on coastal and estuarine studies. SpringerVerlag, Berlin, p 53-83

Wright RT, Hobbie JE (1965) The uptake of organic solutes in lake water. Limnol Oceanogr 10:22-28

Submitted: July 10, 1998; Accepted: February 10, 1999

Proofs received from author(s): August 6,1999 